\title{
INFLUENCE OF KNOWLEDGE WORKERS WORK MOTIVATION ON THEIR JOB PERFORMANCE - RESULTS OF EMPIRICAL RESEARCH
}

\author{
Bieńkowska, A., Ignacek-Kuźnicka, B.
}

Agnieszka Bieńkowska, Beata Ignacek-Kuźnicka / Wroclaw University of Science and Technology,

Faculty of Computer Science and Management, Department of Organizational Management and Development, Wybrzeże Wyspiańskiego 27, 50-370, Wrocław, Poland. Email: agnieszka.bienkowska@pwr.edu.pl; bignacek@gmail.com.

\begin{abstract}
The article focuses on the analysis of the results of empirical research, which shows how motivation of knowledge workers influences their job performance. The analysis focuses on characteristics (that are differentia specifica) of a knowledge worker and their impact on the results achieved in their organization. It was assumed that the impact of motivation on job performance increases together with the intensity of these characteristics. Therefore, the main aim of this article is to verify the influence of motivation on knowledge workers' job performance. In order to verify the formulated hypothesis, an empirical study with the use of a questionnaire was conducted among employees of 204 organizations operating in Poland. Methods of statistical description and estimation were used, including correlation analysis and regression analysis with moderator. A positive relation was established between the absorption of knowledge workers' characteristics and work motivation, and a positive relation between absorption of knowledge workers' characteristics and job performance. Together with the verification of the knowledge workers' characteristics as the mediator of the relation between work motivation and job performance, the study allows for the advancement of the existing (and described) research area. The obtained results allow only to preliminarily verify the raised issue which proves that it is a field of study undoubtedly worth exploring further.
\end{abstract}

Keywords: job performance; knowledge worker; management; motivation

JEL Classification: M12, M50, M10

\section{Introduction}

Technical and manual skills, which are characteristic of mass production, are becoming less dominant in the contemporary economy (Jashapara, 2014). Nowadays, intellectual skills are more important. These are the immanent predispositions of knowledge workers $(\mathrm{KW})$, who differ from other employees in an organization in terms of their level of specialist knowledge, education and experience (Davenport, 2007). By creating, disseminating or using knowledge in practice, these employees are characterized by exceptional qualities and a personal profile (Drucker, 2011; Jashapara, 2014; Klincewicz, 2012; Koźmiński, 
2012; Oleksyn, 2014; Trzcieliński, Włodarkiewicz-Klimek, and Pawłowski, 2013; Wellin, 2013). Moreover, their differentia specifica determines the approach to performing their duties for the organization, which has symptomatic consequences (Kolnhofer Derecskei, Nagy, and Zoltay Paprika, 2017; Kubátová, 2012). This notion has been partially documented in literature, among others, by Bieńkowska and Ignacek-Kuźnicka (2018), who conducted research in a lawyer community. Jashapara (2014) underlined the need to direct the course of the learning process of $\mathrm{KW}$ as a starting point because it results in increased organizational performance. A proper organization of trainings makes $\mathrm{KW}$ more involved (Juhnowicz, 2012), which is reflected in their job performance (Juchnowicz, 2012; Liker, 2016; Šikýr̆, 2013) and also the performance of the organization as a whole (Drucker, 2011). It was also taken into consideration that work motivation itself is one of the factors influencing employees' involvement at work (Wołpiuk-Ochocińska, 2015). This was further supported by Salanova, Agut, and Peiro (2005) who also found that motivation to work is closely related to employees' involvement at work. From this, it is difficult to consider commitment without motivation to work. One of the conclusions in literature was that high work motivation accompanies both high involvement and high performance of employees as well as high performance of the organization as a whole (Bieńkowska and IgnacekKuźnicka, 2018; Tworek, 2019). High involvement from employees is accompanied by high results. For instance, high results obtained by $\mathrm{KW}$ such as lawyers were found to be accompanied by high results obtained by their organizations. Ultimately, the pilot studies performed in organizations operating in Poland showed a strong positive correlation between the percentage of $\mathrm{KW}$ employed in the organization and the creation of new knowledge (Bieńkowska and Ignacek-Kuźnicka, 2017b), thus proving also the legitimacy and purposefulness of continuing research in this field. In view of the above, it seems that the analysis of differences between $\mathrm{KW}$ from other employees in the organization concerning improving the efficiency of $\mathrm{KW}$, development of their individual abilities, the specificity of work culture, increasing loyalty, job satisfaction, their innate and acquired work motivation, as well as the results of their work (Davenport, 2007; Evans, 2005; Fowler, 2015; Huang, 2011; Jezusek, 2018; Jureczka, 2018; Maciariello, 2016; Parmenter, 2016; Pluta, 2018; Šajeva, 2007) still need to be enriched with empirical research in the field of work motivation and job performance. It is true that the above-mentioned articles focus on these issues, sometimes in a very insightful way, but often with the emphasis on developing solutions that would improve the efficiency of KW. However, it seems that the discussion should start with a question of whether the issue of work motivation is really more important for a group of KW than for employees who are not distinguished by any specific skills. Therefore, the main aim of this article will be to verify the influence of work motivation on job performance of $\mathrm{KW}$. Hence, the main scientific question concerns the idea of whether the influence of work motivation on job performance is stronger for $\mathrm{KW}$ than for employees who are not KW. It will allow a focus on the motivation system dedicated to $\mathrm{KW}$ - a matter which translates especially into job performance of these employees and, further, the performance of the organization as a whole.

\section{Literature review and hypotheses development}

\subsection{Knowledge workers in an organization}

The traditional understanding of the term knowledge worker (KW) is characterized by the following distinctions: erudition; excellent education (Kowalski, 2011); ability to provide 
expert opinions (Wellin, 2013); professionalism and a closed catalogue of professions doctor, lawyer, architect (Drucker, 2011; Jashapara, 2014; Kowalski, 2011; Wellin, 2013); autonomy - autonomous participation in knowledge processes, free professions (Drucker, 2011; Jashapara, 2014; Kowalski, 2011; Wellin, 201), professional ethos and moral responsibility (Chong, Ismail, Thi, and Kanafani, 2017; Harlow, 2018; Murgia, Maestripieri, and Armano, 2016). The characteristics of the $\mathrm{KW}$ concept eventually evolved in accordance with the words of Drucker (2011, p.132-133): "Knowledge workers today are productively used in some organizations (...) business entities and state administration.". $\mathrm{KW}$ with highly specialized knowledge have the habit of playing an active and autonomous role in decision-making processes and communicating with employees depending on the logic of a situation and not on the formal structure of competence. Nowadays, a professional ethos is replaced with an individual system of values, prestige and ethical codes. Jashapara (2014) brings KW to the field of culture of individuality, with the autonomy of an individual and collective cooperation giving the opportunity to pursue individual interests. Such culture of individuality should be treated as something that clips differentia specifica and shows the final shape of the knowledge worker's concept. This culture of the individuality of the $\mathrm{KW}$ has its origins in the significant personal profile of an employee and professional passion, which translates into the specifics of motivation to work in an organization (Trzcieliński et al., 2013). The distinctive factors which create the term KW have been partially subjected to empirical research (Bieńkowska and Ignacek-Kuźnicka, 2017b, 2018; Davenport, 2007; Evans, 2005; Fowler, 2015; Huang, 2011; Hvide, and Kristiansen, 2012; Jezusek, 2018; Jureczka, 2018; Maciariello, 2016; Parmenter, 2016; Pluta, 2018; Šajeva, 2007). The constitutive need for autonomy by KW is reflected in the attitude of $\mathrm{KW}$ to the rules on copyrights adopted by organizations (Harlow, 2018; Steinmann and Schreyogg, 2001). Strengthening copyright protection can reduce costs, but can also reduce the efficiency of $\mathrm{KW}$, due to reduced motivation to work. However, innovativeness and cognitive tendencies in an employee's profile have an impact on innovation and efficiency (Lewis, Agarwal, and Sambamurthy, 2003). On the basis of the above, it can be concluded that the most important characteristics of $\mathrm{KW}$ include: ethics (Chong et al., 2017; Evans, 2005; Griffin, 2017; Murgia et al., 2016; Steinmann and Schreyogg, 2001; Tidd, and Bessant, 2013), autonomy (Janz, Colquitt, and Noe,1997; Jungert, Koestner, Houlfort, and Schattke, 2013), cooperation (Davenport, 2007, Jashapara, 2014; Tidd, and Bessant, 2013), professionalism (Frick, 2010; Owen, 2013; Tidd, and Bessant, 2013), intellectualism (Hwang, Kettinger, and Yi, 2015), innovativeness (Fischer, Malycha, and Schafmann, 2019; Tidd, and Bessant, 2013), and reputation (Bhatnagar, Gupta, Alonge, and George, 2017; Frick, 2010; Hwang et al., 2015), as shown in Figure 1. At the same time, it is important to define the concept of the level of absorption of the KW's characteristics. It is not possible to define where the KW begins and ends. It is a continuum of different levels of $\mathrm{KW}$ characteristics saturation.

The characteristics that constitute $\mathrm{KW}$ directly influence the formation of specific human resource management (HRM) solutions dedicated to those employees. KW cannot be managed in the traditional sense. Leaving tradition is a real challenge for the HR managers. The methods that have in the past been effective (e.g. rating systems, payments for performance or bonuses, etc.) are unsuitable for $\mathrm{KW}$ due to their differentia specifica. Whelan and Carcary (2011) emphasize the importance of effective management of employees in an organization, who have key knowledge. The motivational function is 
important from the perspective of an entire organization as well as its individual employees (occupying specific positions). However, there is a research area that still needs to be explored. It concerns the intensity of the determinants constituting $\mathrm{KW}$ characteristics that influence their work motivation and efficiency, translating into organizational performance. Even though Teresa Amabile extensively documented studies related to intrinsic motivation and performance in the workplace (Amabile and Kramer, 2013; Gardner, 2019) there is still a need for further research considering the impact of the strength of $\mathrm{KW}$ characteristics on the relation between work motivation and job performance, which is essential for the possibility to develop dedicated solutions within the framework of incentive systems.

Figure 1 | Characteristics defining KW

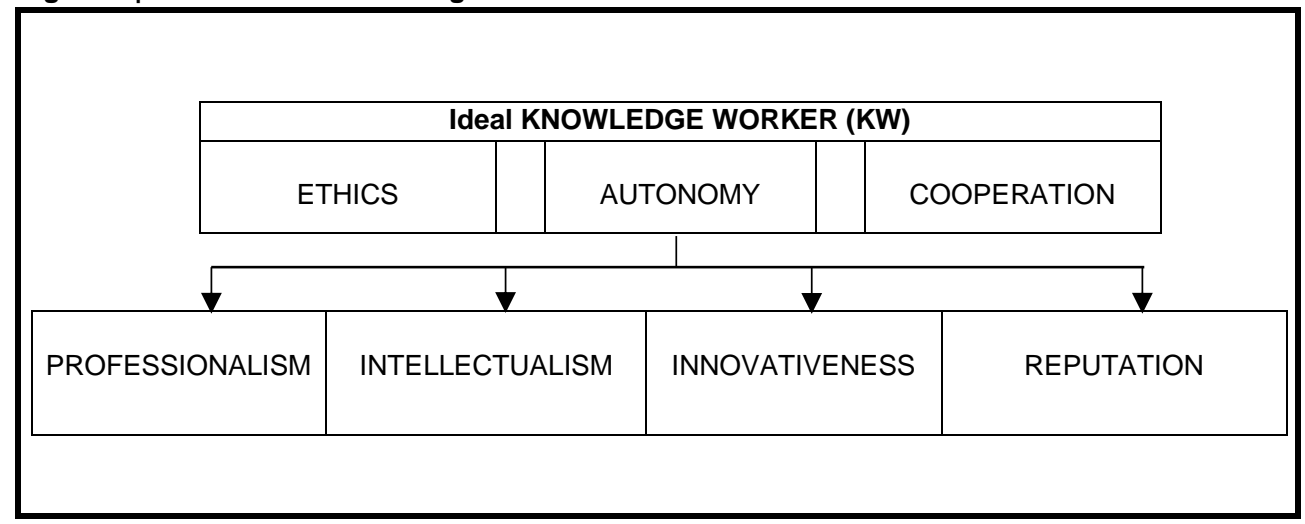

Source: Own work based on Bieńkowska and Ignacek-Kuźnicka (2017)

\subsection{Motivation of KW and their job performance}

Motivation is an internal energy and a personal will to act (Griffin, 2017). After all, as a rule, human behavior is motivated by a specific motive. The research on work motivation shows that its sources, types and quality level are of great importance to the organization (Fowler, 2015; Owen, 2003; Steinman and Schreyogg, 2001).

Literature distinguishes motivation from work motivation. Work motivation (internal work motivation) is traditionally conceptualized as the degree to which the employee is selfmotivated to perform effectively on the job (Hackman and Oldham, 1974; Hackman and Oldham, 1975). Work motivation is a combination of internal emotions and beliefs, e.g.: about the vocation and passion for work, which have an impact on employees, causing them to put more or less effort to do the job (Bhatnagar et al., 2017).

According to the model of Hackman and Oldham (1975), there are three psychological factors shaping work motivation: an employee has to perceive the work as valuable and reasonable, has to have a sense of responsibility for the task and has to know the results (Frick, 2010; Griffin, 2017; Jureczka, 2018; Sadeghi, Sharifian, Sagheb, and Shokrpour, 2019).

The traditional factors of internal work motivation include interesting work and an opportunity to learn and develop (Ding, Babenko, Koppula, Oswald, and White, 2019; Kovach, 1980; Pak, Kooij, De Lange, and Van Veldhoven, 2019; Parmenter, 2016; Steinmann and Schreyogg, 2001). However, as people naturally want to develop, this is not 
the result of any external incentives (Fowler, 2015). The role of internal work motivation is growing in the era of a knowledge-based economy, where $\mathrm{KW}$ are crucial. Building on this, the relation between work motivation and attitude open to innovation was also established (Janz et al., 1997). It was also proved that autonomy is strengthening work motivation and self-efficacy in employees (Jungert et al., 2013). Employees attach great importance to the autonomy and are internally tied to it, and their respect for independence is reflected in internal work motivation (Fowler, 2015; Steinmann and Schreyogg, 2001). KW have enormous energy, that is, they are professionals ready to work day and night. KW exhibit different behaviors as they strive for work and they take responsibility for it with self-control and self-direction. Independence greatly increases their work motivation (Davenport, 2007; Frick, 2010; Maciariello, 2016; Owen, 2003; Tidd and Bessant, 2013). Therefore, it is not surprising that the literature reports that $\mathrm{KW}$ by nature are strongly motivated as their main driving force is coming from autonomy, a sense of a higher purpose and striving for perfection. Due to this, KW put in more effort and take action at work. This demonstrates what can be considered as immanent characteristics of the personal profile of KW (Fowler, 2015). Furthermore, KW are motivated to work with an inner conviction of vocation and selfefficacy (Bhatnagar et al., 2017). Moreover, it was established that creativity and innovativeness (characteristics of $\mathrm{KW}$ ) may be determinants of internal motivation (Fischer et al., 2019).

Consequently, the constitutive characteristics of $\mathrm{KW}$ fit into the motives of internal energy, however it is necessary to conduct research on the consequences of this type of relation. The research that has been done shows that the added value of voluntary efforts (in the case of complex positions occupied by $\mathrm{KW}$ ) of better employees differs by $48 \%$ from the value of average employees (Hunter, Schmidt, and Judiesch, 1990). Therefore, it seems that the level of work motivation will increase with the level of absorption of $\mathrm{KW}$ characteristics, which will mean that $\mathrm{KW}$ are more motivated than employees who are not $\mathrm{KW}$ (who, with the assumption of a continuum of characteristics, are characterized by a low level of absorption of a $\mathrm{KW}$ characteristics). Based on such reasoning, the following hypothesis can be formulated:

H1: The level of absorption of KW characteristics positively affects the level of work motivation.

The economic measures of job performance consist of the behaviour presented as a result of mental and physical effort (input) and the effects of these behaviours (results) (Brumbach, 1988; Griffin, 2017). According to Campbell (1990), job performance can be defined as behaviors and actions determined by an organization's goals. Motowidlo, Borman, and Schmidt (1997) studied the multidimensionality of this notion and stated that it is the total value of the behaviors required from employees. Borman and Motowidlo (in Szara, Ksykiewicz-Dorota, Klukow, and Lamont, 2017) had previously distinguished performance as a formal job description as something contextual, related to a task, or as a voluntary contribution, not related to formal duties. In that regard, task-based performance indicators are leadership and administrative skills, ability to perform job-specific and nonspecific tasks, and communication proficiency (Campbell, 1990). According to Borman and Motowidlo, there are five indicators of the assessment of contextual performance: working for an organization apart from the formal duties of the job description, performing key tasks on time and with enthusiasm, being ready to support colleagues, being compliant with rules 
in difficult circumstances, and being compliant with the organization's policy to defend it goals (Szara et al., 2017).

Given this, the characteristics that identify $\mathrm{KW}$, intuitiveness and creativity, are both important elements of individual behavior in the workplace and they directly or indirectly affect the performance of the organization. They belong to the whole set of efficient behaviors that are expected from a member of the organization. According to Griffin (2017), dysfunctional behaviors are harmful to the organization's performance, and therefore KW characteristics which are counter to dysfunctionality contribute to performance. It was found that for $\mathrm{KW}$, the boundary between professional and personal life is blurred and they work more like volunteers than full-time employees (Evans, 2005). Welch (2005) claims that of the characteristics that an individual brings to the organization their passion stands out as being most fundamental to measuring effectiveness (Parmenter, 2016). Thus, the attitude, individual abilities, and character traits which build the effectiveness of KW work in turn determine the success of the organization (Davenport, 2007; Griffin, 2017; Pluta, 2018). The specific character traits of $\mathrm{KW}$ that provide this progression and contribute to the results of the organization as a whole are idealism, cooperativeness, innovativeness, autonomy, flexibility, high qualifications, interdisciplinarity, openness, illogical development paths, and sense finding (Amstrong and Taylor, 2016; Davenport, 2007; Fowler, 2015; Maciariello, 2016; Tidd and Bessant, 2013). In particular, it has been established that autonomy and cooperation significantly and positively affect the effectiveness of $\mathrm{KW}$ (Davenport, 2007; Janz et al., 1997; Jungert et al., 2013). These common characteristics allow us to treat $\mathrm{KW}$ as a cohesive group in the context of increasing job performance because the factors determining the performance of $\mathrm{KW}$ are identical, regardless of the profession (Davenport, 2007). In spite of this, KW tend to identify more than other workers in an organization with their specialty and to the extent that they may define performance in terms of representatives of their specialization (Griffin, 2017).

Therefore, achieving the best results at work requires a synthesis of three elements: knowledge, skills and will and this combination undoubtedly characterizes KW (Evens, 2005). Organizations achieve better results by employing creative, cooperative employees with excellent skills, characterized by high job satisfaction (Parmenter, 2016). As such, it is understandable that a higher level of contextual performance has been found among KW who identified with the mission and long-term goals of their organization (Szara et al., 2017).

Moreover, numerous empirical studies have proven the existence of the relation between job performance and characteristics of KW (Al-Makhaita, Sabra, and Hafez, 2014; BuljacSamardzic, Dekker van Doorn, van Wijngaarden, and van Wijk, 2010; Fitzpatrick While, and Roberts, 1999). It has also been proven that KW who share their knowledge tend to achieve better results than others (Cummings, 2004). Based on such reasoning, the following hypothesis can be formulated:

H2: The level of absorption of a KW characteristics positively influences the level of job performance.

In general terms, the existence of the relation between work motivation and job performance was already proven in 1974 by Hackman and Oldham (1974). Such a relation also applies to KW. KW differ from other employees, as they have a bigger need for 
autonomy, knowledge, competence, creativity and cooperativeness. That affects their mental states, such as a sense of responsibility, and their personal internal work motivation. It is a specifically conditioned work motivation, which again differentiates $\mathrm{KW}$ from other employees. That is because of different approach to the performed tasks, which translates into personal and organizational results. As a consequence, it is reflected in the level of performance (Davenport, 2007; Deci and Ryan, 2002; Fowler, 2015; Hackman, 1980; Jureczka, 2018). Kelley, 1998; At the same time, the characteristics of KW based on internal emotions, e.g. beliefs about vocation and passion for work, have a profound impact on work motivation and significantly affect behaviors leading to intensification of performance (Frick, 2010). Therefore, the skills and abilities of KW determine the type of internal work motivation specific for $\mathrm{KW}$. The motivation allows to exploit these characteristics, to perform duties at the workplace, thus enabling adequate behavior and actions consistent with the goals of the organization and ultimately its performance. Therefore, work motivation has a much stronger impact on job performance than in the case of employees, who are not KW (Alzaidi, Muneer, and Gaballa., 2011; Fischer et al., 2019). Constitutive characteristics determine KW, generating energy directed at their specific motivators of work, which translates into the best performance of their work in the context of their organization. Therefore, it can be assumed that the impact of work motivation on job performance will be higher among knowledge workers than among other groups of employees. Based on that, the following hypothesis can be formulated:

H3: The higher the level of absorption of $\mathrm{KW}$ characteristics, the higher the influence of work motivation on job performance.

In the light of the above-mentioned considerations, the following research hypotheses can be formulated (Fig. 2):

Figure 2 | Developed hypotheses

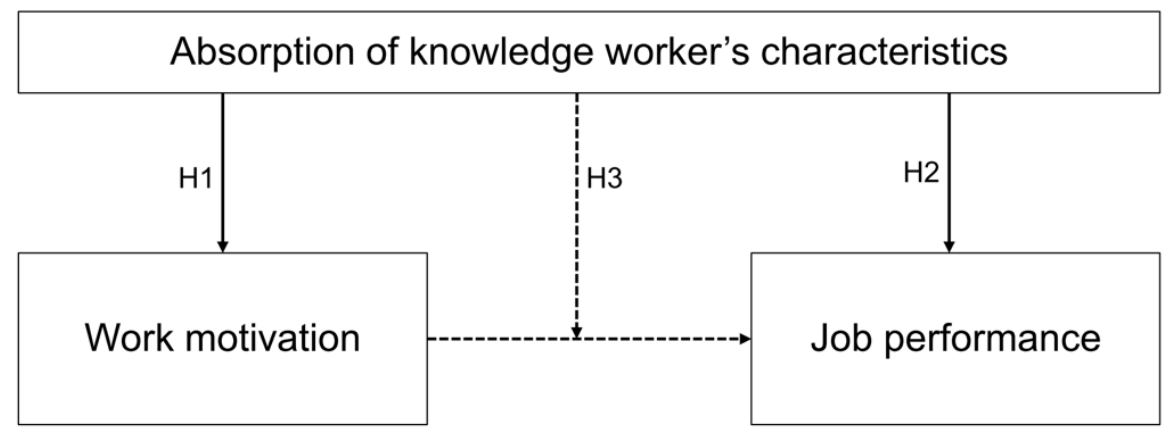

Source: authors

\section{Research methodology and results}

A survey was conducted in order to verify the proposed hypotheses and identify the level of work motivation, job performance and absorption of $\mathrm{KW}$ characteristics. The survey was filled in by employees of organizations operating in Poland. The study involved 204 respondents. One employee from one organization answered the questions in one questionnaire. The responses were gathered using telephone method on the following 
dates: $01 / 03 / 2019,11 / 03 / 2019,19 / 03 / 2019$, and 22/03/2019. A randomly selected group of organizations from the database belonging to IPT Call Center Sp. z o.o. with its seat in Wrocław, Aleja Armii Krajowej 62, with organizations from various industries was used. There were 3985 records in the database.

\subsection{Variables measurement}

In order to examine the proposed hypotheses, key variables were defined: work motivation, job performance and absorption of $\mathrm{KW}$ characteristics. Respondents evaluated all variables based on the list of items using a 7-point Likert scale (the scale from I strongly agree to I strongly disagree with a middle point: I do not have an opinion). The Likert scale is a nominal scale composed of test items in the form of declarative sentences. Each of them has ordinal scales which allow for the characterization of the respondent's attitude towards the phenomenon being measured (Kaczmarczyk, 2003). As Brown (2011) explained, "despite all this discussion of the ordinal nature of Likert items and scales, most of the research based on Likert items and scales...treats them as interval scales and analyzes them as such with descriptive statistics like means, standard deviations, etc." For this reason it is possible to use Cronbach's alpha parameter which estimates the internal consistency reliability of a construct in our analysis (Gay, Mills, and Airasian, 2006).

Work motivation was measured based on the concept of Hackman and Oldham (1974, 1975). The scale contains one item (based on a single question) referring directly to the previously presented definition of work motivation: "I am full of energy and enthusiasm to work in my work position, I am fully committed to the tasks entrusted to me by my organization." Measuring motivation with one statement was dictated by the necessity to condense the phone conversation during which respondents were asked questions.

Job performance was measured according to the definitions by Campbell (1990), Motowidlo, Borman, and Schmidt (1997), and Szara et al. (2017). The scale contains four items referring to the quality, timeliness, efficiency and effectiveness of the employee's tasks at the workplace using the following items:

- I always do all the tasks in the scope of my duties with the quality and performance that satisfies my organization.

- I always fulfill the duties required of my position on time.

- I fulfill my duties effectively.

- I achieve the goals set for me by my organization.

Finally, the absorption of KW characteristics was based on the concept developed by the authors own study based on Bieńkowska and Ignacek-Kuźnicka (2017). In the original version, a scale consisting of 7 items was used and Cronbach's $\alpha$ was 0.777 . Thus, one of the items was eliminated, creating a 6-item scale:

- In my profession I use unique knowledge, which is why I am independent as an expert and at the same time I have great responsibility.

- I am open to interdisciplinary cooperation and sharing my specialist knowledge.

- I do my job in a flexible mode, without any strict supervision, and in the sphere of knowledge I have neither subordinates nor superiors, I have only partners.

- I am an intellectual and I constantly use my knowledge in my organization 
- I create original solutions to the problems that I face and my original ideas are innovative.

- Because of my reputation, position, scope of competence and responsibility, I am an employee who influences the success of my organization.

\subsection{Descriptive statistics and reliability analysis of scales}

As a first step in the research process, the reliability of the scales of each variable was verified. The results of the analysis of the reliability of the measurement scales are presented in tab. 1. Cronbach's $\alpha$ indicates high internal reliability of the scales and measurements.

Table 1 | Defined variables along with the descriptive statistics values and results of the reliability analysis of scales

\begin{tabular}{c|c|c|c|c|c}
\hline No. & Variable & No. of items & Cronbach's $\boldsymbol{\alpha}$ & Mean & $\begin{array}{c}\text { Standard } \\
\text { deviation }\end{array}$ \\
\hline 1 & Work motivation & 1 & -- & 5.809 & 1.1777 \\
2 & $\begin{array}{c}\text { Job performance } \\
3\end{array}$ & 4 & 0.844 & 5.956 & 0.7811 \\
& $\begin{array}{c}\text { Absorption of KW } \\
\text { characteristics }\end{array}$ & 6 & 0.786 & 5.732 & 0.8105 \\
\hline
\end{tabular}

Source: authors

\subsection{Relations between work motivation, job performance and absorption of KW characteristics - research results}

In order to verify hypotheses $\mathrm{H} 1$ and $\mathrm{H} 2$, the correlation coefficient between work motivation, job performance and absorption of $\mathrm{KW}$ characteristics was calculated. The correlation was analyzed with the use of Spearman correlation in order to verify the hypothesis $\mathrm{H} 1$ and $\mathrm{H} 2$. The results are presented in table 2.

Table 2 | Correlation analysis between the work motivation, job performance and absorption of KW characteristics

\begin{tabular}{l|c|c}
\hline Correlation & Work motivation & Job performance \\
\hline Absorption of KW characteristics & $r h o(204)=0.366^{* *}, p<0.001$ & $r h o(204)=0.390^{* *}, p<0.001$ \\
\hline
\end{tabular}

** Significant correlation at 0.01 (two-sided)

\section{Source: authors}

The results show that absorption of $\mathrm{KW}$ characteristics is statistically significantly correlated with work motivation and job performance. The obtained results allow us to accept both hypotheses $\mathrm{H}_{1}$ and $\mathrm{H}_{2}$, regardless of the fact that correlation analysis does not, in general, verify a cause-effect relation. In logical terms, there is only one possible direction of influence: the status of $\mathrm{KW}$ or lack of that status affects work motivation and job performance. However, there is no possibility that the level of work motivation or job performance determines the status of an employee. A high level of work motivation or job performance may reasonably be associated with non-KW. Nevertheless, as the characteristics that have been shown to be correlated with increased work motivation and job performance are standard to $\mathrm{KW}$, this means that $\mathrm{KW}$, on average, have a higher level of work motivation and job performance than employees who do not have this status. 


\subsection{Absorption of $\mathrm{KW}$ characteristics as a moderator for the relations between work motivation and job performance - research results}

The relation between work motivation and job performance (hypothesis $\mathrm{H} 3$ ) was analyzed in the context of absorption of $\mathrm{KW}$ characteristics to verify the statistical significance of this notion as a moderator of the given relation. As a first step, a new variable - moderator was introduced which a product of two standardized, independent variables (work motivation as the first independent variable and absorption of $\mathrm{KW}$ characteristics as the second independent variable). As a second step, a regression model was built using the Process macro for IBM SPSS Statistics. As the first model was built as a base model for comparison, only independent variables were added as predictors. The second model was also built using independent variables together with the moderator as predictors to verify whether the moderating influence is occurring in the entire sample. To confirm that, the third regression model was built using only one independent variable (without absorption of KW characteristics as a second independent variable) and the moderator as predictors. The results of the analysis are presented in table 3.

Table 3 | Regression models' statistics

\begin{tabular}{l|c|c|c|c|c|c}
\hline \multicolumn{1}{c|}{ Model description } & $\mathbf{R}^{2}$ & $\begin{array}{c}\text { Delta } \\
\mathbf{R}^{2}\end{array}$ & $\begin{array}{c}\text { Moderator } \\
\text { coeff. }\end{array}$ & $\begin{array}{c}\text { Standard } \\
\text { error }\end{array}$ & t Stat & $\mathbf{p}$ \\
\hline $\begin{array}{l}\text { Work motivation, } \\
\text { Absorption of KW } \\
\text { characteristics, }\end{array}$ & 0.415 & 0.163 & -0.0713 & 0.0302 & -2.3578 & 0.0193 \\
$\begin{array}{l}\text { Moderator } \\
\text { dependent } v .: \text { job performance }\end{array}$ & & & & & & \\
\hline
\end{tabular}

Source: authors

The obtained model clearly shows that absorption of $\mathrm{KW}$ characteristics is a moderator of the relation between work motivation and job performance (hypothesis H3). The delta R2 and the obtained model for absorption of $\mathrm{KW}$ characteristics as a moderator are statistically significant $(F(3,200)=47,3683, p<0,001)$. In other words, the obtained model confirms the cause-effect relation between work motivation and job performance and allows us to accept hypothesis $\mathrm{H3}$.

\section{Discussion}

Shaping motivation systems dedicated to $\mathrm{KW}$ seems to be a significant issue in the management of modern organizations. A positive relation was established between the absorption of $\mathrm{KW}$ characteristics and work motivation, and a positive relation between absorption of $\mathrm{KW}$ characteristic and job performance. Together with the verification of the $\mathrm{KW}$ characteristics as the mediator of the relation between work motivation and job performance it allows to fulfill to some extent the existing (and described) research area. The R-square value of the constructed model is just over $40 \%$. It is not a high value but acceptable in social sciences (Baguley, 2009; Czakon ed., 2011). It is even believed that in social sciences low R-square values are often expected. Even a low R-square can indicate that regression model has statistically significant explanatory power. The results also fit into the current academic discussion, creating a different picture of an organizational dependency. At the same time, the conclusions contribute partly to the development of 
$\mathrm{HRM}$ as the findings shed new light on the methods of work motivation and performance improvement, as well as the systems of assessments or remuneration. They expand current knowledge about the subject matter and inspire further scientific research in this matter.

The reached conclusions are also relevant to business practice. After all, the performance of an entire organization depends on the behaviour of each employee. If there is a need for knowledge-based work to increase productivity and improve the organization's financial results, appropriate methods for its $\mathrm{KW}$ are needed. For example, in order to effectively and efficiently transfer their knowledge, as demonstrated in practical experiments, specific solutions based on a thorough understanding of their needs and intentions are required (Formánek, 2015). The results of this research initially help to solve these utilitarian problems in the field of KW management. Namely, they allow managers to better understand the basic characteristics of $\mathrm{KW}$ in organizational situations.

\section{Conclusion}

The research gap that is being explored needs to be filled with richer empirical data. One of the reasons for this is the fact that the quantitative method we chose for verification has some limitations. Most importantly, the research was conducted on a randomly selected sample consisting only of organizations operating in Poland and with the use of an innovative tool - a questionnaire constructed by the authors. The obtained results allow only a preliminary verification to the raised issue and just on the basis of the conclusions drawn from them, it is impossible to build a theory for further verification. However, the obtained results revealed that this is a field of study undoubtedly worth exploring. Future research needs to have a bigger sample, that is, a bigger number of respondents, including organizations operating outside Poland. One should also consider whether or not the characteristics of self-motivation or intrinsic motivation should be included in future models.

\section{References}

Al-Makhaita H., Sabra A., and Hafez, A. (2014). Job performance among nurses working in two different health care levels, Eastern Saudia Arabia: A comparative study. International Journal of Medical Science and Public Health, 7(3). Retrieved from Szara, M., Ksykiewicz-Dorota, A., Klukow, J., and Lamont, M. (2017), Przegląd badań nad wydajnością pielęgniarek, available at:https://content.sciendo.com/downloadpdf/ journals/pielxxiw/16/3/article-p51.xml (accessed 1 May 2019).

Alzaidi, A., Muneer, S. E., and Gaballa, A. S. M. (2011). An analytical study of work motivation among the agricultural extension workers in the Kingdom of Saudi Arabia. Arab Gulf Journal of Scientific Research, 29(3-4), 202-214. Retrieved from www.scopus.com_accessed 2 May 2019).

Amabile, T., Kramer, S. (2013). Zasada postępu. Małe zwycięstwa kluczem do radości, zaangażowania i kreatywności w pracy, Gliwice: Wydawnictwo Helion.

Armstrong, M., Taylor, S. (2016). Zarządzanie Zasobami Ludzkimi, Warszawa: Wolters Kluwer.

Baguley, T. (2009). Standardized or simple effect size: What should be reported? British journal of psychology, 100(3), 603-617.

Bhatnagar, A., Gupta, S., Alonge, O., and George, A.S. (2017). Primary health care workers' views of motivating factors at individual, community and organizational levels: a qualitative study from 
Nasarawa and Ondo states, Nigeria", International Journal of Health Planning and Management, 32(2), 217-233.

Bieńkowska A., Ignacek-Kuźnicka B. (2017a). The dilemma of knowledge management in an organization, CBU International Conference on Innovations Science and Educations 2017, 5, $1-6$.

Bieńkowska, A., Ignacek-Kuźnicka, B. (2017b). Świadomość zarządzania wiedzą w organizacji wyniki badań empirycznych. In Nowe aspekty zarządzania organizacjami / red. nauk. Elżbieta Skrzypek, Mariusz Hofman, Grzegorz Grel. Lublin: Katedra Zarządzania Jakością i Wiedzą Wydział Ekonomiczny Uniwersytet Marii Curie - Skłodowskiej, 2017. p.77-87.

Bieńkowska, A., Ignacek-Kuźnicka, B. (2018). Professional trainings of lawyers as an indication of their involvement in the performed work - results of empirical research. In 10th International Conference on Education and New Learning Technologies, EDULEARN18: Palma (Spain), 2nd-4th of July, 2018: conference proceedings/ Ed. by L. Gómez Chova, A. López Martínez, I. Candel Torres. [B.m.]: IATED Academy, cop. 2018. s. 7182-7190. (EDULEARN Proceedings), ISSN 2340-1117.

Brown, J. D. (2011). Likert items and scales of measurement, Statistics 15(1), 10-14.

Brumbach (1988). Retrieved from Armstrong, M., and Taylor, S. (2016). Zarządzanie Zasobami Ludzkimi, Warszawa: Wolters Kluwer.

Buljac-Samardzic, M., Dekker van Doorn C., and van Wijngaarden J., van Wijk, K. P. (2010). Interventions to improve team effectiveness: A systematic review. Health Policy, 94.

Campbell, J. (1990). Modeling the Performance Prediction Problem in Industrial and Organizational Psychology, in: Dunette, M., Hough, M. (Eds), Hendbook of Industrial and Organizational Psychology,vol.1,Wydawnictwo PaloAlto: Consulting Psychologists Press.

Chong, Y., Ismail, M. N., Thi, L., and Kanafani, H. (2017). Managerial virtues: Perspectives of future knowledge workers. International Journal of Economic Research, 14(19), 123-131. Retrieved from www.scopus.com (accessed 2 May 2019).

Cummings, J. (2004). Work groups, Structural Diversity, and Knowledge Sharing in a Global Organization, Management Science 50(3).

Czakon, Wojciech (2011). Podstawy metodologii badań w naukach o zarządzaniu. Wolters Kluwer Polska.

Davenport, T. (2007). Zarządzanie pracownikami wiedzy. Kraków: Oficyna a Wolters Kluwer business.

Deci, E., Ryan, R. (2002). Handbook of Self-Determination Research, Rochester: University of Rochester Press. Retrieved from Fowler, S. (2015), Dlaczego motywowanie ludzi nie działa...i co działa. Warszawa: MT Biznes sp. z o.o.

Ding, M., Babenko, O., Koppula, S., Oswald, A., and White, J. (2019). Physicians as teachers and lifelong learners. Journal of Continuing Education in the Health Professions, 39(1), 2-6. doi:10.1097/CEH.0000000000000228.

Drucker, P. (2011). Menedżer skuteczny. Warszawa: Wydawnictwo NT Biznes.

Evans, C. (2005). Zarządzanie wiedzą. Warszawa: Polskie Wydawnictwo Ekonomiczne.

Fischer, C., Malycha, C.P., and Schafmann, E. (2019). The influence of intrinsic motivation and synergistic extrinsic motivators on creativity and innovation, Frontiers in Psychology, 10(2).

Fitzpatrick, J., While, A., and Roberts, J. (1999). Shift work and its impact upon nurse performance: current knowledge and research issues, J Adv Nurs, 29(3). 
Fowler, S. (2015). Dlaczego motywowanie ludzi nie działa...i co działa. Warszawa: MT Biznes sp. z o.o.

Formánek, I. (2015). Knowledge management as an important part of strategic management. Retrieved from http://www.wsb.edu.pl/container/FORUM\%20SCIENTIAE/forum\%202015\%20nr\%203/forum2015-3-art5.pdf

Frick, D. E. (2010). Motivating the knowledge worker. DEFENSE INTELLIGENCE AGENCY WASHINGTON DC.

Gardner, H. (2019). Creativity and Creativities: The Challenges Ahead. Retrieved from https://howardgardner01.files.wordpress.com/2019/08/festschrift-for-teresa-amabile.pdf (accessed 2 May 2019).

Gay, L. R., Mills, G. E., and Airasian, P. W. (2009). Educational research: Competencies for analysis and applications. Merrill/Pearson, pp.141-142.

Griffin, R. (2017). Podstawy zarządzania organizacjami. Warszawa: Wydawnictwo Naukowe PWN SA.

Hackman, J. R. (1980). Work redesign and motivation. Professional Psychology, 11(3), 445-455.

Hackman, J. R., Oldham, G. R. (1974). The job diagnostic survey: An instrument for the diagnosis of jobs and the evaluation of job redesign projects (Tech. Rep. No. 4). New Haven, Conn.: Yale University, Department of Administrative Sciences.

Hackman, J. R., Oldham, G. R. (1975). Development of the Job Diagnostic Survey. Journal of Applied Psychology, 60(2), 159-170.

Harlow, H. (2018). Ethical concerns of artificial intelligence, big data and data analytics. Paper presented at the Proceedings of the European Conference on Knowledge Management, ECKM, 1316-323. Retrieved from www.scopus.com (accessed 2 May 2019).

Huang, T. P. (2011). Comparing motivating work characteristics, job satisfaction, and turnover intention of knowledge workers and blue-collar workers, and testing a structural model of the variables' relationships in China and Japan. The International Journal of Human Resource Management, 22(04).

Hunter, J. E., Schmidt, F.L., and Judiesch, M.K. (1990). Individual differences in output variability as a function of job complexity, Journal of Applied Psychology, 75(1). Retrieved from Amstrong, M., Taylor, S. (2016). Zarządzanie Zasobami Ludzkimi. Warszawa: Wolters Kluwer.

Hvide, H. K., Kristiansen, E. G. (2012). Management of Knowledge Workers. The Journal of Law and Economics, 55(4), 815-838. JSTOR. Retrieved from www.jstor.org/stable/10.1086/666587 (accessed 2 May 2019).

Hwang, Y., Kettinger, W.J. and Yi, M.Y. (2015). Personal information management effectiveness of knowledge workers: Conceptual development and empirical validation, European Journal of Information Systems, 24(6), 588-606.

Janz, B. D., Colquitt, J. A., and Noe, R. A. (1997). Knowledge worker team effectiveness: The role of autonomy, interdependence, team development, and contextual support variables. Personnel psychology, 50(4), 877-904.

Jashapara, A. (2014). Zarządzanie wiedzą. Warszawa: Polskie Wydawnictwo Ekonomiczne.

Jezusek, M. (2018). Praca zespołowa. In Biesok, G., Wyród-Wróbel, J. (Ed.), Człowiek w organizacji. Zaufanie, przywództwo, zaangażowanie, satysfakcja. Warszawa: Wydawnictwo CedeWu Sp. Z o.o. 
Juchnowicz, M. (2012). Zaangażowanie pracowników. Sposoby oceny i motywowania. Warszawa: Polskie Wydawnictwo Ekonomiczne.

Jungert, T., Koestner, R.F., Houlfort, N. and Schattke, K. (2013). Distinguishing source of autonomy support in relation to workers' motivation and self-efficacy. Journal of Social Psychology, 153(6), 651-666.

Jureczka, K. (2018). Satysfakcja z pracy. In: Biesok, G., Wyród-Wróbel, J. (Ed.), Człowiek w organizacji. Zaufanie, przywództwo, zaangażowanie, satysfakcja. Warszawa: Wydawnictwo CedeWu Sp. z o.o.

Kaczmarczyk, S. (2003). Badania marketingowe. Metody i technik. PWE, Warszawa, pp.127-129.

Kelly, R. (1998). How to be a Star at Work: 9 Breakthrough Strategies You Need to Succeed. Times Book, New York. Retrieved from Davenport, T. (2007). Zarządzanie pracownikami wiedzy, Kraków: Oficyna a Wolters Kluwer business.

Klincewicz, K. (2012). Cele zarządzania wiedzą, In: Jemielniak, D., Koźmiński, A.K. (eds.), Zarządzanie wiedzą. Warszawa: Oficyna a Wolters Kluwer business.

Kolnhofer Derecskei, A., Nagy, V., and Zoltay Paprika, Z. (2017). How Can Creative Workplaces Meet Creative Employees? Central European Business Review, 6(4), 3-19. doi: 10.18267/j.cebr.187.

Kovach, K. (1980). Why Motivational Theories Dońt Work, Society for Advancement of Management, 45(2).

Kowalski, T. (2011). Pojęcia i cechy pracownika wiedzy, Studia lubelskie, t. VII.

Koźmiński, A. (2012). Wstęp. In Jemielniak D., Koźmiński A.K. (Ed.), Zarządzanie wiedzą. Warszawa: Oficyna a Wolters Kluwer business.

Kubátová, J. (2012). The Influence of National Culture on Knowledge Management in China Managerial Implications for Central European Countries. Central European Business Review, 1(1), 20-26. doi: 10.18267/j.cebr.4.

Lewis, W., Agarwal, R., and Sambamurthy, V. (2003). Sources of Influence on Beliefs about Information Technology Use: An Empirical Study of Knowledge Workers, MIS Quarterly, 27(4), 657-678. Retrieved from www.jstor.org/stable/30036552 (accessed 2 May 2019).

Liker, J. (2016). Droga Toyoty 14 zasad zarządzania wiodącej firmy produkcyjnej świata. Warszawa: Wydawnictwo MT Biznes.

Maciariello, J. (2016). Rok coachingu z Peterem Druckerem. Warszawa: MT Biznes sp. z o.o.

Motowidlo, S., Borman, W., and Schmidt, N., (1997). A theory of individual differences in task and contextual performance, Human Performance, 10.

Murgia, A., Maestripieri, L., and Armano, E. (2016). The precariousness of knowledge workers: Hybridisation, self-employment and subjectification. Work Organisation, Labour and Globalisation, 10(2), 1-8. doi:10.13169/workorgalaboglob.10.2.0001

Oleksyn, T. (2014). Zarządzanie zasobami ludzkimi w organizacji. Warszawa: Oficyna a Wolters Kluwer business.

Owen, J. (2003). Zarządzanie. Czego nie uczą w szkołach biznesu. Warszawa: Polskie Wydawnictwo Ekonomiczne.

Pak, K., Kooij, D. T. A. M., De Lange, A. H., and Van Veldhoven, M. J. P. M. (2019). Human resource management and the ability, motivation and opportunity to continue working: A review of 
quantitative studies. Human Resource Management Review, 29(3), 336-352. doi:10.1016/j.hrmr.2018.07.002.

Parmenter, D. (2016). Kluczowe wskaźniki efektywności (KPI). Tworzenie, wdrażanie i stosowanie. Gliwice: Wydawnictwo Helion.

Pluta, A. (2018). Kształtowanie sprawności pracowników wiedzy działających pod presją czasu, Szczecin: Wydawnictwo Naukowe Uniwersytetu Szczecińskiego.

Sadeghi, K., Sharifian, R., Sagheb, Z. M., and Shokrpour, N. (2019). Perception of job characteristics and internal motivation in medical records staff. Indian Journal of Public Health Research and Development, 10(1), 478-483. doi:10.5958/0976-5506.2019.00094.

Salanova M., Agut S., Peiro, J. M. (2005). Linking organizational resources and work, engagement to employee performance and consumer loyalty: The mediation of service climate, Journal of Applied Psychology, 90, 1217-1227.

Steinmann, H., Schreyogg G. (2001). Zarządzanie. Podstawy kierowania przedsiębiorstwem. Koncepcje, funkcje, przykłady. Wrocław: Oficyna Wydawnicza Politechniki Wrocławskiej.

Szara, M., Ksykiewicz-Dorota, A., Klukow, J., and Lamont, M. (2017). Przegląd badań nad wydajnością pielęgniarek. Retrieved from https://content.sciendo.com/downloadpdf/ journals/pielxxiw/16/3/article-p51.xml (accessed 1 May 2019).

Šajeva, S. (2007). Identifying factors affecting motivation and loyalty of knowledge workers. Economics and Management.

Šikýř, M. (2013). Best Practices in Human Resource Management: The Source of Excellent Performance and Sustained Competitiveness. Central European Business Review, 2(1), 4348. doi: 10.18267/j.cebr.38.

Tworek, K. (2019). Aligning IT with business. Cham: Springer.

Tidd, J., Bessant, J. (2013). Zarządzanie innowacjami. Integracja zmian technologicznych, rynkowych i organizacyjnych. Warszawa: Oficyna a Wolters Kluwer business.

Trzcieliński, S., Włodarkiewicz-Klimek, H., and Pawłowski, K. (2013). Współczesne koncepcje zarządzania. Poznań: Wydawnictwo Politechniki Poznańskiej.

Welch, J., Welch, S. (2005). Winning znaczy zwyciężać, Warszawa: Studio Emka. Retrieved from Parmenter, D. (2016), Kluczowe wskaźniki efektywności (KPI). Tworzenie, wdrażanie $i$ stosowanie. Gliwice: Wydawnictwo Helion.

Wellin, M. (2013). Zarządzanie kontraktem psychologicznym. Zaangażowanie pracowników w zwiększenie wydajności firmy. Warszawa: Oficyna a Wolters Kluwer business.

Whelan E., Carcary M. (2011). Integrating talent and knowledge management: where are the benefits? Journal of Knowledge Management, 15(4).

Wołpiuk-Ochocińska A. (2015). Motywacje do pracy i zaangażowanie w nią młodych pracowników na rynku pracy, Katowice: Zeszyty Naukowe Wyższej Szkoły zarządzania ochroną pracy w Katowicach, 1(11)/2015.

The research paper has been reviewed. | Received: July 21, 2019; Revised: October 6, 2019; Accepted: November 6, 2019; Prepublished online: January 22, 2020; Published: January 30, 2020 